\title{
Challenges and Opportunities for Extension Educators Involved in Best Management Practices
}

\author{
Eric H. Simonne and Monica Ozores-Hampton
}

AdDITIONAL INDEX WORDS. total maximum daily load, nitrogen, fertilization, irrigation, vegetable crops

\begin{abstract}
SUMMARY. With the development and implementation of best management practices (BMP), extension educators are facing a new and unexpected combination of challenges and opportunities. Because the BMP mandate requires a combination of research, demonstration, and outreach, it may affirm the relevance of the land grant mission in the 21 st century, engage universities in interagency alliances, and help rediscover the wonders of the proven extension method. The extension approach to water and nutrient management needs to shift from "pollute less by applying less fertilizer" to "pollute less by better managing water." Applied research is leading to advances in areas such as nutrient cycles and controlled-release fertilizers. At the same time, universities need to walk a fine line between education and regulation, address perennial issues of overfertilization, and consider the reformulation of recommendations that are now used in a quasi-regulatory environment. A combination of education, consensus, and novel approaches is needed to adapt the rigor of research to a multitude of growing conditions and risks of nutrient discharge in order to comply with U.S. federal laws and restore water quality.
\end{abstract}

$\mathrm{T}$

The U.S. federal Clean Water Act of 1977 (U.S. Congress, 1977) required that states assess the impact of non-point sources of pollution on surface and ground waters, and establish programs to minimize them. Section 303(d) required states to identify impaired water bodies and establish total maximum daily loads (TMDLs) for pollutants entering these water bodies. By definition, a TMDL is the maximum amount of a pollutant (or contaminant) that a water body can receive from point and non-point sources and still have its water quality meet the standards defined for its intended use. The main pollutants associated with vegetable production are nitrate concentration, phosphate concentration, and total dissolved solids. A TMDL also provides an allocation of pollution among landowners within a watershed [Florida Department of Environmental Protection (FDEP), 2005a]. Once a TMDL is established for a pollutant in a watershed, a 5-year implementation plan [also called basin management action plan (BMAP)] is developed. The BMAP specifies the activities that watershed landowners will undertake to reduce

Horticultural Sciences Department, University of Florida Institute of Food and Agricultural Sciences, Gainesville, FL 32611-0690. point and non-point sources of pollution (FDEP, 2005b). As a response to the federal TMDL mandate, the Florida legislature passed the Florida Watershed Restoration Act (Florida Senate, 1999). This legislation gave the Florida Department of Agriculture and Consumer Services (FADCS) the authority to develop BMP interim measures, BMPs, cost-share incentives, and other assistance programs to help all segments of agriculture reduce pollutant loads in target watersheds. BMPs are defined by FDACS, as specific cultural practices aimed at reducing the negative environmental impact of agricultural production while increasing or maintaining economical yields. BMPs intend to be educational, economically sound, technically feasible, environmentally robust, and based on science. Hence, BMPs are tools to achieve the TMDLs.

FDACS has taken a commodity approach to BMP development (FDACS, 2005a). The "WaterQuality/Quantity Best Management Practices for Florida Vegetable and Agronomic Crops" manual is the document that describes the BMPs that will apply to vegetable and row crops in Florida (FDACS, 2005b). It has been adopted by reference in Rule 5M-8 of the Florida Administrative Code (FDACS, 2006). The manual l) 
provides background on the statewide BMP program, 2) lists all the possible BMPs that may apply to vegetable production, 3) provides a selection mechanism for building a customized BMP plan for each farming operation, 4) outlines record-keeping requirements, and 5) explains how growers can officially participate in the BMP program. The manual is a resource document that cites existing publications from the National Resource Conservation Service (NRCS), the University of Florida Institute of Food and Agricultural Sciences (UF-IFAS), and the Federal Insecticide, Fungicide and Rodenticide Act amended by the Food Quality Protection Act (U.S. Congress, 1996). Water quality is the responsibility of the landowner, but the responsibility may be shared by growers through land leases. By law, growers who participate in the BMP program will 1 ) receive a waiver of liability from reimbursement of cost and damages associated with the evaluation, assessment, or remediation of nitrate contamination of ground water, 2 ) be granted a presumption of compliance with water quality standards, and 3 ) be eligible for cost-share programs designed to offset the cost of BMP implementation. The BMP program is voluntary, but once a BMAP has been developed for a watershed, nonparticipating growers will be required to show that they do not exceed their load allocation by monitoring off-site nutrient movement from their operations.

The Florida BMP manual for vegetables was developed between 2001 and 2005 under the leadership of a steering committee that included stakeholder representatives from FDACS, FDEP, the water management districts, UF-IFAS, the Florida Fruit and Vegetable Association, NRCS, the Florida Farm Bureau, and growers. Because the manual adopts UF-IFAS production recommendations, it gives extension a central role in the success of this program. At the same time, the nontraditional role of an educational institution such as UF-IFAS in a quasiregulatory program comes with new and sometimes unexpected opportunities and challenges. The following discussion uses the vegetable BMP program in Florida as an illustration of these opportunities and challenges, knowing that these topics may apply to other land grant institutions and edu- cational organizations in other states, and different commodities.

Opportunity 1. Maintain the RELEVANCE OF THE LAND GRANT MISSION IN THE 21 st CENTURY. Water quality is a topic of public importance, and therefore fits into the land grant mission. From an academic standpoint, the BMPs have created a need in several areas of knowledge that have required the integration of applied research and extension. As most BMPs focus on nutrient and irrigation management, interest in fertilization programs and irrigation scheduling has increased. While it has been long known that fertilizer efficiency typically ranges between $40 \%$ and $60 \%$ (actual efficiency depends on growing conditions and the definition of efficiency used), the fate of the nutrients that are not taken up by plants needs to be clarified. Mineralization, leaching, and denitrification are now fields of active investigation. Improving water quality has created the need to document the increases in water quality (decreases in discharge) attributable to individual or sets of BMP ("validation of BMPs"). The approach has consisted of direct water quality measurement in experimental fields and/or prediction of water quality by modeling and simulation at the watershed level. A second approach to documenting the efficacy of BMPs has been the direct measurement of nutrient discharge through leachate collection or soil sampling. Such research typically involves multiyear, large-scale projects that are funded by state or federal agencies, or combined sources.

OpPortunity 2. Engage UNIVERSITIES IN INTERAGENCY ALLIANCES. Partnerships between growers, universities, and state agencies have become a creative and inclusive approach to BMP education. The Suwannee River Partnership (SRP) is a unique example of multiagency cooperation in Florida. The SRP is a coalition of 50 state, federal, regional and local governments, and private industry partners, which mission is to determine the sources of nutrient loads to the Suwannee River and Santa Fe River basins, and to work with local land users to minimize future nutrient loading through voluntary, incentive-based programs (SRP, 2005). The innovation comes from state agencies such as FDEP with a regulatory mission now actively participating in nonregulatory, incentive-based, and educational programs in cooperation with UF-IFAS. Another innovative approach to cooperation is the joint creation by UF-IFAS and the SRP of "educational coordinator" positions which role is to bridge the agenda and mission of both partners through education. In short, this type of educational coordinator may be regarded as a multiagency educational agent.

OPPORTUNITY 3. REDISCOVER THE WONDERS OF THE PROVEN EXTENSION METHOD. In its contemporary sense, the goal of extension programming is to create a specific change in behavior of a defined segment of clientele. Universities have a long history of fertilization (Hartz and Hochmuth, 1996; Mikkelsen and Bruulsema, 2005) and irrigation (Locascio, 2005) involvement. In addition, educating growers on water and nutrient BMPs requires an unbiased approach that integrates the rigor of research together with the reality of farm production. Because each farm represents a different economical unit and because the BMP program allows for the development of farm-specific BMP programs, the educational effort on BMPs requires on-farm demonstration, with active grower involvement. Hence, the onesize-fits-all approach is inappropriate.

The research methods typically used on research plots need to be adapted to the realities of on-farm production (Baldwin, 2004). While on-farm research on topics that require single or few operations (such as variety, fumigant, herbicide, or pesticide evaluation) can be tested with limited disturbance to daily farm operations, on-farm testing of fertilization and irrigation practices requires daily activities and are likely to disturb routine farming operations. Moreover, implementing replicated and randomized factorial combinations of irrigation and fertilization practices with drip irrigation may not be possible during a single year (Simonne et al., 2002a). Hence, on-farm researchers are often limited to two single-plot treatments (grower's method and alternate method) that can only be replicated in time.

The extension method has historically found its strength from oneon-one education with growers. The process of BMP adoption is a slow one involving human perceptions. Together with research and demonstration, BMP education and implementation also rely on best professional 
judgment. Therefore, it is important to incorporate as much flexibility into the process as possible. Adoption of improved practices is a stepwise process, with initial steps not often able to withstand careful research scrutiny (Mylavarapu, 2003).

Opportunity 4. Change eduCATIONAL PARADIGM. Nutrient management education for vegetables has been historically based on the "pollute less by applying less fertilizer" approach. With the development of BMPs, this paradigm has to be replaced with "reduce off-target fertilizer movement through increased water management". While both approaches recognize the importance of load reduction, the new paradigm emphasizes the vector (water) over the pollutant (fertilizer). In Florida, such change in paradigm in vegetable extension has facilitated interactions with vegetable growers and has allowed extension educators to abandon the unpopular "use less fertilizer" rhetoric and transition into programs that focus on irrigation scheduling and soil moisture measurement (Munoz-Carpena et al., 2002; Simonne et al., 2002b). Through on-farm demonstrations, it has appeared that the obstacles to increased irrigation management often have their roots in inadequate irrigation system design, poor modifications of well-designed irrigation systems, and lack of understanding of the connection between fertilization and irrigation. Through combinations of lectures by industry representatives and university personnel, updates by members of state agencies, hands-on demonstrations in the field, and practical calculations of fertilizer and irrigation rates, the Florida drip irrigation school provides a day-long educational program that teaches participants how to better manage drip irrigation (Simonne, 2003; Simonne et al., 2002). Based on pretraining and post-training test scores, participants increased their knowledge by $+23 \%$ during these educational programs and have increased their understanding of BMPs.

While much extension effort has been done in the past to improve nutrient management of horticultural crops [e.g., strawberry (Fragaria $\times$ ananassa) in northern Florida (Hochmuth et al., 2003a)], irrigation management has been limited by the fact that it is difficult to visualize water movement in the soil. Dye tests have been an ef- fective teaching tool with growers who use drip irrigation. Dye tests typically consist in injecting a soluble dye with the irrigation water, followed by increasing irrigation time, excavating the root zone, and observing and measuring the position of the dye (Simonne et al., 2004). Sequential dye injection through the growing season allowed cucurbit growers in north Florida to visualize how excessive irrigation during the first third of the growing season pushed the dye below the root zone, and supported the need for adjustments to their irrigation schedules (Simonne et al., 2005).

Opportunity 5. Potential for THE DEVELOPMENT OF CROP-SPECIFIC CONTROLLED-RELEASE FERTILIZERS (CRF). Water is the vector of off-site nutrient movement during erosion and/or leaching. While reducing fertilizer rates and real-time irrigation scheduling have long been recognized as good growing techniques, reducing the risk of nutrient leaching by using nonsoluble forms of fertilizers has been little used in vegetable production in the past (Mikkelsen and Bruulsema, 2005; Simonne and Hutchinson, 2005). The release pattern of today's polymer-coated urea or polymer sulfur-coated urea fertilizer products is more predictable that the ones containing polymerized chains of urea (Conner, 1996). Consequently, testing CRFs for potato (Solanum tuberosum) production has been an area of intense research efforts in recent years (Pack et al., 2006; Simonne and Hutchinson, 2005; Zvomuya and Rosen, 2001). These efforts have resulted in the development of a CRFbased fertilization program based on a $38 \mathrm{~N}-0 \mathrm{P}-0 \mathrm{~K}$ PotatoBlen (The Scotts Co., Marysville, Ohio) which will be available to potato growers in Florida for the 2005-06 growing season (W. Kuzey, personal communication) at a per-acre basis cost that is competitive with the cost of current soluble fertilizer programs (Hutchinson and Simonne, 2003). This CRF-based program is economically competitive with current programs by combining reduced rates allowed by CRF, controlling product availability through distributors/applicators, and a lowcost pricing strategy adopted by the manufacturer. While fertigation allows for flexibility in fertilizer applications, CRFs are mostly suited for vegetable grown without drip irrigation (on bare ground, or with plastic mulch and seepage irrigation). Potato, tomato (Lycopersicon esculentum), and bell pepper (Capsicum annuum) are major vegetable crops grown with seepage irrigation in Florida for which CRFbased fertility programs are under development.

In practice, each opportunity comes with its own challenge, and vice versa. For clarity of presentation, they are presented separately.

Challenge 1. University's HISTORICAL ROLE IS EDUCATION, NOT REGULATION. Typically, farmers do not like regulation. The association of land grant universities with quasi-regulatory efforts may be interpreted by some farmers as a change in the university's agenda and may result in 1) erosion of grass-root support to universities, 2) universities having to "take sides" in a pollution-production polarized environment, and 3 ) loss of credibility of county agents who directly interact with growers. Informal surveys of growers reveal that it is still unclear to them if the goal of the BMP program is to put them out of business or clean the environment. Overcoming these challenges will require a major educational effort.

Challenge 2. The BMP proGRAM HAS TO DEAL WITH OLD ISSUES. In the context of competitive agriculture, growers tend to view fertilizers as an inexpensive insurance and tend to overfertilize. For a wide range of reasons, current UF-IFAS fertilizer recommendations have been poorly adopted by the vegetable industry. Hence, the BMP manual includes some flexibility beyond the recommendations in order to increase the program appeal. As described in the "optimum nutrient management" BMP, vegetable and row crops growers have three basic options in their approach to fertilizer management: 1) use UF-IFAS recommendations or alternative recommendations from a credible research institution; 2) use UF-IFAS recommendations as a starting point, employ additional BMPs using the BMP assessment checklist; and 3 ) farmers in significantly impaired basins must follow recommendations in the BMAP (FDACS, 2005b). Option 2 should not be regarded as a license to overfertilize, but as a means to allow for a transition period in BMP adoption. The length of this transition period is likely to be related to documented 
improvements, or lack thereof, in water quality.

While the BMP manual elegantly added flexibility to the UF-IFAS fertilizer recommendations, the role and responsibility of commercial soil testing laboratories and/or crop consultants who make fertilizer recommendations are yet to be defined. Their active participation in states like Florida, where the bulk of commercial soil testing and fertilizer recommendations is made through parties other than UF-IFAS, is likely to affect the rate of adoption and success of the BMP program.

Challenge 3. As university's PRODUCTION RECOMMENDATIONS ARE GIVEN A NEW ROLE, A NEW FORMAT IS NEEDED FOR FERTILIZER RECOMMENDATIONS. By adopting UF-IFAS recommendations, the $\mathrm{BMP}$ manual interprets production recommendations in a new manner. From "a" possible successful way of producing vegetables, recommendations adopted as BMPs may become "the" legal way of producing vegetables. This raises the fundamental question of what is the definition of a recommendation? Surprisingly, no clear definition of "what is a recommendation" was found in the extension literature in Florida. Item 6 in the extension specialist's role and responsibility document states that the specialist "synthesizes, integrates, evaluates, and applies research information and expertise into educational programming materials (fact sheets, software, computer files, publications, videos, etc.) to support the statewide extension education program" (Woeste et al., 2005). The UF-IFAS pesticide recommendation document states that "persons making fertilizer recommendations have similar responsibilities to those making pesticide recommendations, even though fertilization applications are not regulated as are pesticide applications. Fertilization recommendations should take into consideration environmental and management factors which will influence the nutritional benefit of the fertilizer $[\ldots]$, the potential adverse effects $[\ldots]$, soil test levels of nutrients, water management practices, proximity to water bodies, potential runoff and leaching, fertilizer application techniques, as well as nutrient rates. Recommendations must be consistent with the IFAS standardized fertilization recommendation system" (Olexa et al., 2001). The Florida vegetable handbook is defined as "a comprehensive guide designed to bring growers the latest information about successful vegetable production" (Olson and Simonne, 2005). The handbook also reports that "fertilizer recommendations that have been developed from research and on-farm experience with optimum water management" (Hochmuth and Hanlon, 2000). The UF-IFAS nutrient management series publications state that "These ranges [of recommended fertilizer applications] determine the amount of a nutrient that should be applied for successful crop production based on the crop nutritional requirement" (Mylavarapu, 2002). The crop nutritional requirement for a particular element is defined as the total amount in pounds per acre needed by the crop to produce economic optimum yield (Olson and Simonne, 2005). While all these statements are consistent with common knowledge and mention the importance of soil testing and irrigation management, they only imply a high chance of success when UF-IFAS fertilizer recommendations are followed in conjunction with other production factors at optimal level. When growers had no regulatory pressures, the "gray zone" surrounding the recommendations was acceptable. Now that recommendations may become quasiregulatory, the chances of economical success when recommendations are followed need to be quantified. Since this may be difficult to accomplish, recommendations need at least to include flexibility that allows for a high chance of economical success under a wide range of growing conditions including soil type, irrigation method, or planting date. Hence, the current format of UF-IFAS fertilizer recommendations for vegetables may need to be modified.

Challenge 4. Adapting the FORMAT OF FERTILIZER RECOMMENDATIONS FOR VEGETABLES TO MAKE THEM REFLECT LOCAL GROWING CONDITIONS. When most vegetable crops were grown on bare ground, nitrogen $(\mathrm{N})$ fertilizer recommendations consisted of a total number (a blanket rate when no soil test was available, and a soiltest-based rate otherwise) divided into a preplant rate and one, two, or three sidedress applications. Occasionally, methods of application and/or placement (broadcast, modified broadcast, or banded) were specified. With the adoption of plasticulture for the pro- duction of high-value vegetable crops, the entire field surface is no longer fertilized or irrigated. This format of recommendation was replaced with a standardized fertilization recommendation which took into account bed spacing and reflected that rows of plants, not surfaces, are fertilized and irrigated (Hochmuth and Hanlon, 2000). The UF-IFAS N fertilizer recommendations are currently based on single rates (not ranges) which are different for sandy (Olson and Simonne, 2005), muck (Hochmuth et al., 2003b), and calcareous (Li et al., 2002 ) soil types. Current UF-IFAS $\mathrm{N}$ recommendations also allow for supplemental fertilizer application. Single-rate recommendations may be justified on the basis that the crop nutritional requirement in theory does not change, and that they are simpler to formulate. Yet, standardized fertilizer recommendations need to be further fine-tuned in the context of BMPs to include irrigation method (drip or seepage) and growing season (spring, fall, or winter). For example, it seems unrealistic to recommend the same $\mathrm{N}$ rate for tomato grown in the spring with plasticulture and drip irrigation (for a 13-week growing season) and one grown in the winter with seepage irrigation (for a 19-week growing season). Different $\mathrm{N}$ rates may be justified under different growing systems or planting seasons, but also by different potential denitrification rates (Simonne and Morgant, 2005). In short, the one-size-fits-all approach may not apply to fertilizer recommendations in states with widely different growing conditions. While extensive site- and season-specific research could lead to localized recommendations, it may be more practical on an interim basis to replace single fertilizer rates by ranges. These ranges may be qualified by footnotes. Because some watersheds are $\mathrm{N}$-limited and others are phosphorus-limited, the emphasis of fertilizer recommendation should focus on the limiting nutrients in each watershed.

\section{Conclusions}

Nutrient and irrigation management are at the center of the BMP effort. Yet, the development and implementation of BMPs for vegetable is not business as usual. Extension educators have to fully adapt to new quasi-regulatory challenges, but remain unbiased and true to the research method at 
the same time. How can we change and yet retain our ethical and scholarly principles? Integration of research and extension, multiagency partnerships, appropriate funding, grower involvement, and education are likely keys to the success of the BMP program. While these challenges may appear daunting, the alternative to this voluntary program is regulation.

\section{Literature cited}

Baldwin, K.R. 2004. A field guide for onfarm research experiments. 15 Oct. 2005 <http://griffin.uga.edu/sare/pdf_files/ fieldguide.pdf $>$.

Conner, A.H. 1996. Urea formaldehyde adhesive resins, p. 8497-8505. In: J.C. Salamone (ed.). Polymeric materials encyclopedia. CRC Press, Boca Raton, Fla.

Florida Department of Agriculture and Consumer Services. 2005a. Best management practice forms, documents and manuals. 21 Oct. 2005. <http://www.floridaagwaterpolicy.com/BestManagementPractices.html>.

Florida Department of Agriculture and Consumer Services. 2005b. Water quality/quantity best management practices for Florida vegetable and agronomic crops. 21 Oct. 2005. <http://www.floridaagwaterpolicy.com/ PDFs/BMPs/vegetable\&agronomicCrops. pdf>.

Florida Department of Agriculture and Consumer Services. 2006. Best management practices (BMPS) for Florida vegetable and agronomic crops. Florida Department of Agriculture and Consumer Services Rule 5M-8. 13 Mar. 2006. <http://fac.dos.state. fl.us/faconline/chapter05.pdf>.

Florida Department of Environmental Protection. 2005a. Total maximum daily loads: Background information. 21 Oct. 2005 <http://www.dep.state.fl.us/water/tmdl/ background.htm>.

Florida Department of Environmental Protection. 2005b. Total maximum daily loads: Draft verified lists of impaired waters for the group 3 basins. 21 Oct. 2005. <http://www.dep. state.fl.us/water/tmdl/verified_gp3.htm>.

Florida Senate. 1999. Florida Water Restoration Act (TMDL bill) SB 2282, Florida Statutes Title XXIX, Ch. 403.067. 13 Mar. 2006. <http://www.flsenate.gov/ Statutes $/$ index.cfm?App_mode $=$ Display_ Statute\&Search_String $=\& U R L=C h 0403 /$ SEC067.HTM\&Title $=->2005->$ Ch0403$>$ Section\%20067\#0403.067>.

Hartz, T.K. and G.J. Hochmuth. 1996. Fertility management of drip-irrigated vegetables. HortTechnology 6(3):168-172.

Hochmuth, G.J. and E.A. Hanlon. 2000. IFAS standardized fertilization recommendations for vegetable crops. Electronic Data Info. Source Circ. 1152. 21 Oct. 2005. <http://edis.ifas.ufl.edu/CV002>.
Hochmuth, R., D. Dinkin, M. Sweat, and E. Simonne. 2003a. Extension programs in Northeastern Florida help growers produce quality strawberries by improving water and nutrient management. Electronic Data Info. Source HS 956. 21 Oct. 2005. <http://edis. ifas.ufl.edu/HS190>.

Hochmuth, G., E. Hanlon, G. Snyder, R. Nagata, and T. Schueneman. 2003b. Fertilization of sweet corn, celery, romaine, escarole, endive, and radish on organic soils in Florida. Electronic Data Info. Source Bul. 313. 21 Oct. 2005. <http://edis.ifas.ufl. edu/CV008>.

Hutchinson, C.M. and E.H. Simonne. 2003. Controlled-release fertilizer opportunities and costs for potato production in Florida. Electronic Data Info. Source HS 187. 21 Oct. 2005. < http://edis.ifas.ufl.edu/review_hs187>.

Li, Y.C., H.H. Bryan, W. Klassen, M. Lamberts, and T. Olczyk. 2002. Tomato production in Miami-Dade County, Florida. Electronic Data Info. Source HS 858. 21 Oct. 2005. < http://edis.ifas.ufl.edu/TR014>.

Locascio, S.J. 2005. Management of irrigation for vegetables: Past, present, and future. HortTechnology 15(3):482-485.

Mikkelsen, R.L. and T.W. Bruulsema. 2005. Fertilizer use for horticultural crops in the U.S. during the 20 th century. HortTechnology 15(1):24-30.

Munoz-Carpena, R., Y. Li, and T. Olczyk. 2002. Alternatives of low cost soil moisture monitoring devices for vegetable production in South Miami-Dade county. Electronic Data Info. Source ABE 333. 21 Oct. 2005. <http://edis.ifas.ufl.edu/AE230>.

Mylavarapu, R.S. 2002. UF/IFAS nutrient management series: UF/IFAS standardized nutrient recommendation development process for successful crop production and environmental protection. Electronic Data Info. Source SL 189.21 Oct. 2005. <http:// edis.ifas.ufl.edu/SS401 >.

Mylavarapu, R.S. 2003. Role of an extension soil testing program in the development of best management practices: A Florida case study. J. Ext. 4l(4). 21 Oct. 2005. <http:// www.joe.org/joe/2003august/a7>shtml >.

Olexa, M.T., N. Nesheim, and G. Kidder. 2001. IFAS pesticide and fertilizer recommendations. Electronic Data Info. Source FE 272. 21 Oct. 2005. <http://edis.ifas. ufl.edu/FE272>.

Olson, S.M. and E.H. Simonne. 2005. Vegetable production handbook for Florida. Vance Publ., Lenexa, Kans.

Pack, J.E., C.M. Hutchinson, and E.H. Simonne. 2006. Controlled-release fertilizers for northeast Florida chip potato production and soil nitrogen management J. Plant Nutr. 29:(In press).

Simonne, E. 2003. Learning to better manage: The Florida drip irrigation school. Univ. Fla.
Inst. Food Agr. Sci. Nutr. Mgt. Educ. Core Group Nwsl. 3:3-4. 21 Oct. 2005. <http:// soils.ifas.ufl.edu/extension/2003Newsletter. pdf>.

Simonne, E.H. and B. Morgant. 2005. Denitrification in seepage irrigated vegetable fields in south Florida. Electronic Data Info. Source HS 1004.21 Oct. 2005 <http://edis. ifas.ufl.edu/HS248>.

Simonne, E.H. and C.M. Hutchinson. 2005. Controlled-release fertilizers for vegetable production in the era of best management practices: Teaching new tricks to an old dog. HortTechnology 15(1):36-46.

Simonne, E.H., D.W. Studstill, M.D. Dukes, R.C.Hochmuth, W.E. Davis, G. McAvoy, and J.R. Duval. 2002a. Custom-made drip-irrigation systems for integrated water and nutrient management research and demonstration. Proc. Fla. State Hort. Soc. 115:214-219.

Simonne, E., D. Studstill, B. Hochmuth, T. Olczyk, M. Dukes, R. Munoz-Carpena, and Y. Li. 2002b. Drip irrigation: The BMP era-An integrated approach to water and fertilizer management in Florida. Electronic Data Info. Source HS 917. 21 Oct. 2005 <http://edis.ifas.ufl.edu/HS172>.

Simonne, E., D. Studstill, M. Dukes, J. Duval, R. Hochmuth, E. Lamb, G. McAvoy, T. Olczyk, and S. Olson. 2004. How to conduct an on-farm dye test and how use its results to improve drip irrigation management in vegetable production. Electronic Data Info. Source HS 980.21 Oct. 2005. <http:/ / edis. ifas.ufl.edu/HS222>.

Simonne, E.H., D.W. Studstill, R.C. Hochmuth, J.T. Jones, and C.W. Starling. 2005. On-farm demonstration of soil water movement in vegetables grown with plasticulture. Electronic Data Info. Source HS 1008. 21 Oct. 2005. <http://edis.ifas.ufl. $\mathrm{edu} / \mathrm{HS} 25 \mathrm{l}>$.

Suwannee River Partnership. 2005. Background. 15 Dec. 2005. <http://mysuwanneeriver.com/features/suwannee+river+pa rtnership>.

U.S. Congress. 1977. Clean Water Act. PL 95-217, 27 Dec. 1977. U.S. Statutes At Large 91:1566-1611. U.S. Govt. Printing Office, Washington, D.C.

U.S. Congress. 1996. Food Quality Protection Act. PL 104-170, 3 Aug. 1996. U.S. Statutes At Large 104:1489-1538. U.S. Government Printing Office, Washington, D.C.

Woeste, J.T., C.T. Waddill, and L.R. Arrington. 2005. Extension specialist's role and responsibility statement. Electronic Data Info. Source Circ. PE 63. 21 Oct. 2005. <http://edis.ifas.ufl.edu/SD055>.

Zvomuya, F. and C.J. Rosen. 2001. Evaluation of polyolefin-coated urea for potato production in sandy soil. HortScience 36(6):1057-1060. 